\title{
The Linacre Quarterly
}

Volume 53 | Number 2

Article 11

May 1986

\section{Near Death Out-of-Body Experiences: How Might a Catholic Doctor React to Them?}

Douglas Flippen

Follow this and additional works at: http://epublications.marquette.edu/lnq

\section{Recommended Citation}

Flippen, Douglas (1986) "Near Death Out-of-Body Experiences: How Might a Catholic Doctor React to Them?," The Linacre Quarterly: Vol. 53 : No. 2 , Article 11.

Available at: http://epublications.marquette.edu/lnq/vol53/iss2/11 


\title{
Near Death Out-of-Body Experiences: How Might a Catholic Doctor React to Them?
}

\author{
Douglas Flippen
}

The author received his master's degree in medieval studies from the Center for Medieval Studies, University of Toronto, his medieval studies licentiate from the Pontifical Institute of Medieval Studies, Toronto, and his doctorate in philosophy from the University of Toronto. He has taught at the University of St. Thomas and the Center for Thomistic Studies in Houston and at Carroll College. Helena. Montana.

It is becoming increasing difficult to ignore near-death experiences, including those involving an out-of-body component. The number of such experiences seems to have increased because of improvements in lifesaving techniques and technology. More experiences are being reported by patients, both because more researchers are looking for such experiences, and because more patients realize others have had similiar experiences so that they are not a freak of nature, and not something one should be ashamed to acknowledge. From the 1975 Life After Lifel work of Raymond A. Moody, Jr., philosopher turned doctor, to Adventures in Immortality, ${ }^{2}$ a work by the pollster, George Gallup, Jr. and William Proctor, there has been a veritable flood of publications on the topic. Researchers in the field include cardiologists and others in the medical profession, psychologists, sociologists, psychiatrists, philosophers, scientists in other areas of study, and others. Moody, Kubler-Ross ${ }^{3}$, Rawlings ${ }^{4}$, Sabom $^{5}$ and Schoonmaker $^{6}$ are among those who represent the medical profession. Osis ${ }^{7}, \mathrm{Haraldsson}^{8}$, $\mathrm{Ring}^{9}$, and $\mathrm{Kletti}{ }^{10}$ are researchers from the area of psychology. Noyes 11 and Ritchie ${ }^{12}$ are psychiatrists. Kreutziger ${ }^{13}$ is an assistant professor of social work in psychiatry. Lundahl ${ }^{14}$, Widdison ${ }^{15}$ and Hart ${ }^{16}$ are sociologists. Grosso ${ }^{17}$, Price ${ }^{18}$, Ducasse ${ }^{19}$ and James ${ }^{20}$ are representatives from the area of philosophy. Crookall ${ }^{21}$ is a botanist and geologist who became preoccupied with the 
subject, and Monroe 22 is an engineer-businessman who became interested after his own personal experiences of being outside his body.

An out-of-body experience is one in which the person having the experience is convinced that he, as a conscious being, is really present in a given location, and yet is not present there in a tangibly physical way. One who hallucinates is commonly aware of hallucinating. One having an out-of-body experience has no inclination to say he is hallucinating. It is as real as any event he has previously experienced. A common circumstance for an out-of-body experience is when one is taken to the hospital in a critically ill state and is pronounced dead, while being worked on. A number of such patients have subsequently (after resuscitation) reported watching the doctors working on their lifeless body from the ceiling or from a corner of the room near the ceiling. Many patients have been able to give very clear accounts of what they saw going on in the room (or even down the hall) while they were supposedly dead.

Many who have investigated the phenomena have become convinced of the objective reality of such experiences, while some (e.g., Noyes and Kletti) have remained skeptical. Of those who have not seriously investigated the matter, many, if not most, who regard themselves as scientific or philosophically oriented tend to reject the reports of such occurrences out of hand. Such a rejection and refusal to take the matter seriously is probably due to the dogmatically empiricist temper of the modern mind which simply refuses to admit the existence of the possibility of a natural knowledge of immaterial realities. The dogmatic empiricist is simply one who holds that since all human knowledge comes from the senses, nothing that transcends the senses can be known by us. Materialism or naturalism simply concludes from this line of thinking that if immaterial realities cannot be known by us, then they do not exist as far as we are concerned. But empiricism is a philosophical theory which, even though it currently dominates the intellectual scene and enters into the popular conception of the scientific method, still remains more a working hypothesis than, a proven one. In short, it would be well to keep an open mind concerning the topic, as Harold Widdison reminds us in his essay, "Near-Death Experiences and the Unscientific Scientist." 23

Reports of such experiences date from at least the time of Plato, although it is difficult to say if Plato's Myth of Er in The Republic is factually based. Moody refers to historical parallels and accounts both in Life After Life and in Reflections on Life After Life. John Audette has an essay entitled "Historical Perspectives on Near-Death Episodes and Experiences" in a work edited by Craig Lundahl ${ }^{24}$. The work Adventures in Immortality ${ }^{25}$, by Gallup and Proctor, indicates that nearly three million Americans have had a near-death experience.

\section{Importance of the Topic}

It is almost unnecessary, given the association of doctors and nurses with patients near death or those who have been resuscitated from a death-like condition, to indicate the relevance of such experiences from the practicing physician or nurse. At the same time, one must admit that experiences 
which seem to challenge our philosophical and religious convictions are rather unsettling. If a human being can leave his body, it seems clear that a human cannot simply be identified with his body, empiricist assumptions notwithstanding. But what are the alternatives if person and body are not identical? Are we a soul imprisoned for a time in a body, as Plato would have it? Or are we the dual substance, mind and body, Descartes thought we were? Neither possibility squares too well with the facts of human experience, as Ryle ${ }^{26}$ and St. Thomas ${ }^{27}$ have pointed out. And what about religious beliefs? The vast majority of those having a near-death experience have had an extremely pleasant one, suggesting bliss or happiness in their afterlife. Very few have had a terrifying experience. What then of hell? What about purgatory? What of the account of Lucy of Fatima ${ }^{28}$ and Anna Maria Taigi $^{29}$, indicating from their visions of after life conditions that all too many are bound for hell, a fair number for purgatory and very few straight for heaven? The accounts do not agree too well with each other. Is the conflict real or merely apparent?

\section{Aristotelian Psychology and Out-of-Body Experiences}

One reason for beginning with a consideration of Aristotle's psychology is that the very way in which he tried to stick as close as possible to the facts of human experience inclined him to leave the question of the human soul's survival after death an open one. Aristotle did not solve the problem of whether the human soul is separable from the body. If we set aside the troublesome Chapter 5 of Book 3 of his work On the Soul. we are left with several arguments for the separability of the human soul (Book 3. Chapter 4), and one major objection to the separability of the soul (Book 3. Chapter 7). In short, we do not know how to reconcile the arguments for and against the separability of the human soul in Aristotle. This gave rise to various interpretations of what Aristotle really had in mind. But if we stick to the texts, we must say that what Aristotle really had in mind is that there is a problem concerning the separability of the human soul which he could not see how to solve. Why is there a problem?

In Chapter 4 of Book 3, Aristotle argues in effect that, whereas sensation appears clearly dependent on having a body, intellectual activity does not. If a human being (as intellectual) can perform any activity which is independent, in some way, of the body, then it seems possible in theory for a human being as intellectual to exist independent of a body. As a thing is, so does it act and, conversely, actions reveal something of the being and nature of a thing. If a person can act independently of the body, then a person can exist independently of the body. Chapter 7 of Book 3 raises an objection to this possibility. Even if intellectual activity as such seems independent of the body, still it presupposes a product of sensation in two ways: a) the objects of intellectual activity are initially abstracted or drawn from the products of sensation (as when we abstract the notion of two from two pears, two apples, two pieces of chalk, etc.), b) the objects of intellectual activity refer to the products of sensation in some way to refer to what is real (as when we mentally refer an abstract notion of justice or beauty or 
love to a concrete example which we have or could have experienced through the senses) since it is via the senses that we immediately are aware of what actually exists. Since the senses are clearly dependent on the body and the intellect is in some way dependent on the senses, it seems a person could not function, even intellectually, apart from the body. And if a person can in no way function apart from the body, what sense does it make to say he or she can exist (as person) apart from the body? The problem is clear.

What do out-of-the-body experiences, as occuring especially to those near death, have to do with the problem of the separability of the soul in Aristotle's psychology? Simply this: reports of out-of-the-body experiences, whether near death or no, indicate that while the senses of touch, taste and smell cease to function, and hearing seems not so much like hearing as reading the thoughts of others, the sense of sight seems intact and even enhanced, ${ }^{30}$ If true, this would remove Aristotle's objection against the separability of the soul as having an intellect. But how could any sense function in the complete absence of the body? The experiences seem to indicate that the body is not completely absent. The person undergoing the experience is aware of having a body of sorts. Sometimes doctors or friends have said they have seen a body of sorts forming above the body of one who was dying. The so-called body is sometimes described as like a mist or vapor, as being ethereal or light-like. It is not my interest to inquire into the precise nature of such a body. But if there is a body of sorts which one retains at death, and if that body enables at least one sense to function, the Aristotle's insurmountable objection to the soul's separability is no longer insurmountable. One's condition as a human being would be unnatural, to be sure, but not so unnatural that one could not function as an intellectual agent.

\section{Thomistic Psychology and Out-of-Body Experiences}

Some arguments against the survival of death and personal immortality are easy to deal with; others are not so easy. The argument that, since death is annihilation of the person, there can be no survival by definition is easy to deal with just because it is an argument which follows from a contested definition. The empiricist assumes that the person is no more than an organization of matter. When that lump of organized matter becomes sufficiently disorganized, no more person. But what if we do not take empiricism for granted and we argue for the immateriality and separability of the soul from the body on the basis of the abstract character of intellectual operations? Then death. the death of the body is its being separated from the soul which is the source of its life as a human body. An argument which arises here against survival of the person is that after the death of the body we would no longer have the same nature or kind of being. nor the individual person. We would no longer have the same kind of being because of the removal of one of its substantial parts. The implicit analogy here is that just as with the removal of oxygen from water you no longer 
have water at all but merely hydrogen, something substantially different, so with the removal of the body from the soul-body combination you would no longer have human but merely soul. What is one to respond here? Clearly a Platonist, or one who defines the human as only a thinking soul to begin with, would reject the analogy with water or $\mathrm{H}_{2} \mathrm{O}$. The argument would be most disturbing to one who thinks of a human as a combination of two substances, body and soul. Such a view is sometimes attributed not only to Descartes, but also, because of ignorance, to the greater part of the medieval tradition, including St. Thomas Aquinas. ${ }^{31} \mathrm{St}$. Thomas, however, would have rejected the analogy. St. Thomas, elaborating on Aristotle's view and modifying it, is in agreement neither with Plato nor with Descartes. If the soul has an operation independent of the body then the soul is an agent of substantial being independent of the body. The body, on the other hand, having no operation independent of the soul, is no agent or substantial being independent of the soul. The human being is not two things or substances yoked together but is only one. That one includes body and soul as natural parts, against Plato, but not as parts which stand on the same footing as substances, as against Descartes. A human being is not so much a rational animal (which seems to emphasize the bodily aspect as most substantial) as a naturally incarnate rational soul (which emphasizes the substantial character of the soul). ${ }^{32}$ With the death of the body, the soul loses that which it naturally needed to act as a rational agent. One of two things happens at that point. If death is the complete loss of the body, then the soul would need extraordinary or miraculous aid to continue to function at all. In the view of St. Thomas, such aid would be supplied by God. ${ }^{33}$ The soul would continue in existence as a human being incomplete in nature, but still substantially the same. It would still be that kind of thing which naturally belonged in a body and operating through a body, i.e., it would still be human. The other thing which could happen is indicated by out-of-body experiences. If death is the loss of the major part of the body but not all of it, then we are still dealing with a rational soul which is not only potentially, but still actually incarnate in a minimal sense. Death would be like a more radical version of losing your limbs and parts of your trunk. ${ }^{34}$ The condition of the rational soul would still be an unnatural one: three, if not four, of the five human senses would have ceased to function. Yet the condition would not be as unnatural as if the entire body were lost at death. To the argument, then. which concluded that at death we would no longer have the same kind of being. i.e., a human being, the response is that we would, since the rational soul as a being, to whom it belongs by nature to exist in and operate through a body, would not have changed. Its condition of being without a body, either wholly or for the most part, is unnatural, but does not ruin its status as a certain kind of rational agent. The way in which out-of-body experiences affect the traditional argument is indicated by the difference between potentiality and actuality. The soul, instead of potentially being 
joined to and operating through a body, would still actually joined to and operating through a body of sorts. ${ }^{35}$

\section{The Individual Surviving Death}

What about the argument against the individual as individual surviving death? Can one argue that, if one is incomplete in nature with the death of the body, then one is incomplete in being, and if incomplete in being, then one is no longer the same in being? Or can one argue, as St. Thomas does, setting the dual substance view aside, that the being of the body as a human body is not owned by the body but is only communicated to it by the soul, and upon death of the body, the person is the same individual being, albeit in the unnatural condition of lacking a body? And if we call to mind the Aristotelian-Thomistic notion that matter is the principle of individuation, out-of-body experiences would seem to make the continued individuation of the soul by matter easier to understand - if a body of some kind remains bound up with the soul.

Although the continued presence of a body of sorts might make some problems easier to handle for those of a strong empiricist bent, still it seems to raise certain problems of its own. If a near-death, out-of-body experience involves the soul plus minimal body being separated in place from the tangible and visible body, has one really died or not? If the answer is yes (as in the case of Lazarus in the New Testament), then there is no problem. But what about those times when the answer is no? When one's body has not completely ceased to function, and especially when some consciousness of being in the tangible body remains, and yet one claims an out-of-body experience, we are brought face to face with a serious problem. Has one person become two and then one again? Consider the reported cases of dual consciousness. One is aware, for example, both of sitting in a chair resting and of being (in a "spiritual body") in the next room or even miles away. And one can report on what is happening in both places in a verifiable way. What can be said of one's unity as a conscious being in such a case? This is no new problem for the Christian tradition. We are faced with this problem every time we hear of the bilocation of some holy person. How can one person be bodily present in two different places and still be one person? St. Augustine was suspicious of the reality of such an experience and was inclined to attribute it to demonic deception. St. Thomas characterized bilocation as a contradiction. Yet reports of bilocation have persisted through the history of the Church, right down to the Padre Pio in our own times. The bilocation of saints seems to be a special case of out-of-body experiences, i.e., supernaturally caused out-of-body experiences. Can it be defended as being as real as it seemed to those to whom it occurred? Do those to whom it occurred actually claim that they bilocated?

This latter question can be answered with a quotation from Rev. Charles Carty's biography of Padre Pio: 
One evening. Dr. Wm. Sanguinetti (faithful friend and personal physician of Padre Pio) tells us that he and a few others were in Padre Pio's room, when the doctor opened the following conversation:

Dr.: "Padre Pio. when God sends a saint, for instance like St. Anthony to another place by bilocation, is that person aware of it?"

Padre Pio: "Yes. One moment he is here and the next moment he is where God wants him."

Dr:: "But is he really in two places at one?"

Padre Pio: "Yes."

Dr.: "How is this possible?"

Padre Pio: "By a prolongation of his personality." 36

The reason for questioning Padre Pio about bilocation is that he was reported to have been seen often in distant places while still present in San Giovanni. Without putting him on the spot, as is were, Dr. Sanguinetti was asking him about his own experience with bilocation. Padre Pio's explanation, brief though it is, should be carefully noted. He did not say that one's personality or consciousness was split and separately present in two different places. That was the problem St. Thomas had with bilocation. For a person to be present in two different places, as wholly enclosed in two separate places, would have meant the person was not one, but two. Padre Pio's response suggests that perhaps something else has occurred. If a prolongation of one's personality or consciousness is what has literally occurred, and if consciousness is in a body of some kind, then perhaps a prolongation of one's body has also occurred. In that case the person would not be wholly contained in two separate places, but would be in one extended place. Bilocation would be apparent but not literally true. In short, the two bodies would be connected in a bodily way. This is perhaps to stretch the quotation from Padre Pio, but it is true that some researchers into out-of-body experiences have spoken of a pulsating or light-like cord connecting the tangible body and the vapor-like body in which consciousness is centered. ${ }^{37}$

\section{Medical Implications of the Cord}

If a cord is present connecting the two bodies, then one is inclined to say that the person having an out-of-body experience is not dead, no matter how many signs of life are absent. Even if there are no detectable brain waves, and such cases have been reported,$^{38}$ one cannot say the person is certainly dead. Corruption would seem to be the safest of all signs of death, but one could even be uncertain about it as a sign in those cases where some bodily parts have begun to corrupt before death. Just as very many persons seem to have been mistakenly buried alive, so it is also likely that many deaths have been hastened by removing usable organs from patients at the earliest signs of death.

This is not to say that there are no sure cases in which usuable organs could be taken from one presumed dead with no fear that one was hastening the process of dying. Since the brain is the most essential of the bodily parts, and the one part which could not be transplanted without 
transplanting the very person whose brain it was, usable organs may be taken from a body from which the head has been severed. Even if it takes some time for the soul to separate from the body at death and for the cord (if there is such a thing) connecting the intangible body with the tangible one to be severed, in cases where the head has been severed from the body, the soul and intangible body ought to be present with the brain, rather than with the rest of the body, and to be separating from it.

How long does it take for the soul and the intangible body to separate from the tangible body at death, or how long does it take before the cord connecting the two bodies is severed and death has certainly occured? The cases reported leave the answer somewhat in doubt. The process ordinarily begins with the cessation of vital signs, but the only case I have noticed where an observer watched the process from beginning of separation to the severing of the cord, indicates it may take two to three hours. ${ }^{39}$ At the severing of the cord, the observer also noticed the definite relaxation of the facial muscles of the deceased.

\section{Religious Implications of Near Death Out-of-Body Experiences}

It is no secret, at the present time, that the vast majority of those having some near death out-of-the-body experience have reported quite pleasant experiences. Many investigators have taken this as a clear suggestion that there is no punishment after death, i.e., no hell or purgatory wherein one is punished for the rest of eternity or purified for a time. Such a suggestion reinfores the post-Vatican II distortion of God as One Who loves and is merciful and never punishes. For this reason alone, many who have managed to preserve the balanced view of God as One Who is not only loving and merciful, but also One Who is rigorously just in punishing sin, have been highly suspicious of the whole business of reports of out-ofbody experiences. What should be said of this?

That one has reason to suspect the conclusion that there is no hell or purgatory awaiting us after death is indicated by all those Christian visionaries down through the ages, and into our own time, who have been granted visions of purgatory or hell. A wealth of such accounts is contained in the work by Rev. F. X. Shouppe, S.J., entitled Purgatory: Illustrated by the Lives and Legends of the Saints. ${ }^{40}$ Some indication of how many people might actually go to hell and how serious the possibility is can be gleaned from the 19th century Catholic mystic Anna-Maria Taigi. from Lucy and Jacinta of Fatima in the beginning of our own century, and from the recently reported apparitions (not yet officially approved) of the Virgin Mary at Medjugorje in Yugoslavia.

Anna-Maria Taigi had a vision of souls departing the earth after death, and said, concerning them:

Very few, not as many as ten. went straight to heaven; many remained in purgatory, and those cast into hell were as numerous as flakes of snow in mid-winter. ${ }^{41}$ 
In 1953, Lucy of Fatima was being interviewed by the Jesuit priest Rev, Lombardi. The part of the interview bearing on hell, as quoted in a recent book on Fatima, is as follows:

"Tell me", said Fr. Lombardi, "is the Better World movement a response of the Church to the worlds spoken by Our Lady?"

"Father", Lucia replied, "there is certainly a great need for this renewal. If it is not done. and taking into account the present development of humanity, only a limited number of the human race will be saved."

"Do you really believe that many will go to Hell?" Father Lombardi asked. "I hope that God will save the greater part of humanity." (He had just written a book entitled: Salvation for Those Without Faith.)

"Father, many will be lost."

"It is true that the world is full of evil, but there is always a hope of salvation."

"No, Father, many will be lost."42

And little Jacinta, who was so deeply impressed by her vision of hell on July 13, 1917, would remark about so many souls going to hell. ${ }^{43}$

From the reported apparitions at the present time in Medjugorje, Yugoslavia, we have the following remark on purgatory and hell from one of the visionaries, who had asked the Blessed Mother about it:

"Did the Madonna tell you whether many people go to hell today?"

"1 asked her about that recently, and she said that today most people go to purgatory. The next greatest number go to hell, and only a few go directly to heaven." 44

Such reminders of the reality of hell and of the very real possibility of going there do not sit well with many at the present time. The revelations are indeed private, but considering the sources and the fruits of the lives and activities of the visionaries concerned, it seems highly imprudent to ignore what seem like warnings and reminders.

It is just because they seem to create a sense of false security and the ignoring of the seriousness of sin, that the vast number of highly pleasant. near death out-of-body experiences are characterized by some religious thinkers as the work of Satan, at least in part. ${ }^{45}$ That this suspicion may not be an idle or fanatical one is indicated by Ralph Martin's comment on Elisabeth Kubler-Ross. In his work, A Crisis of Truth: The Attack on Faith, Morality, and Mission in the Catholic Church, he writes as follows about the very influential Dr. Kubler-Ross:

Kubler-Ross gave numerous seminars, many of which were attended and sponsored by church people. In them, often in response to questions, she would tell of her admiration for Mother Teresa and then go on to explain that her research with the dying indicated there was no "judgemental" God... .

As her fame and influence grew. Dr. Kubler-Ross began to talk about a "pleasant state" that existed beyond death, one into which everybody entered irrespective of religious belief or of the moral quality of one's life. She also became involved in spiritualism and attempted to communicate with the dead. ...

In 1979, the depth of Kubler-Ross" bondage to "spirits" became public when she declared herself to be an "immortal visionary and modern cartographer of 
the River Stix" and defended her deep involvement with a spiritualist group called the Church of the Facet of Divinity. . .

In recent appearances and interviews. Kubler-Ross openly admits that she has had contact with "spirit guides" for nine years and that they have told her that there is no such thing as damnation, judgement, or hell.

Although now professing disillusionment about her heavy dependence on a particular psychic. her non-Christian occult views remain unchanged:

"There is no such thing as good or bad. If we don't learn what we're supposed to in this life, we'll learn it in another."

Besides Dr. Kubler-Ross, other investigators have drawn the conclusion from reports of near death experiences that there is no judgemental God and no damnation or hell. ${ }^{47}$ And yet there are reported cases of experiences of hell, or something very like it, by those having near death experiences. They are not many, but a few of them suggest that actual experiences of hell may be far greater than the reports indicate. Just as children may form multiple personalities in order to escape facing an overwhelmingly cruel environment, ${ }^{48}$ so also many who find themselves personally consigned to hell in a near-death experience may simply suppress the experience and fail to recall anything but pleasant experiences afterward. Two such cases are reported by Dr. Maurice Rawlings in his work, Belond Death's Door. ${ }^{49}$ Rawlings opens his book with an account of a man who suffered a cardiac arrest and dropped dead in his office. Rawlings set to work to resuscitate him. Whenever the man would regain heartbeat and respiration, he would scream that he was in hell and would plead with Rawlings not to stop his resuscitation attempts. When Rawlings got up the nerve, a couple of days later, to interview his patient about his experiences of hell, the man recalled none of it. All he could remember was a pleasant experience of seeing his mother and stepmother and the out-of-body experience of watching Rawlings' resuscitation attempts. But although he could not consciously recall his unpleasant experience, the man became markedly more religious after it.

Such an experience may explain why survivors of suicide attempts who have only recalled pleasant out-of-body experiences, have little or no inclination to repeat the attempt. This is a somewhat puzzling phenomenon for which investigators offer no convincing explanation. One would think that a pleasant out-of-body experience by one who had reason to commit suicide would only reinforce the attempt to be successful. ${ }^{50}$ One such suicide attempt with a suppression of a seeming experience of hell and a subsequent conversion to a religious life is recounted by Rawlings. A 14-year old girl attempted suicide with an aspirin overdose and had a cardiac arrest from inhaling her own vomit. At one point she kept saying:

\footnotetext{
"Mama help me! Make them let go of me! They're trying to hurt me!" The doctors tried to apologize for hurting her. but she said it wasn't the doctors. but "Them, those demons in hell ... they wouldn't let go of me . . . they wanted me, .. I couldn't get back, , ., It was just awful!"
}

After the various tubes were removed. I asked her to recall what had 
happened. She remembered taking the aspirin, but absolutely nothing else!

She subsequently became a missionary several years later. No despondency. ${ }^{51}$

These two cases of suppression of an extremely unpleasant near-death experience suggest that there may be a serious methodological flaw to most near-death studies. As conscientiously scientific as many researchers into near-death experiences may be, they omit, almost to a man, the possibility that their patients have suppressed extremely unpleasant experiences. Almost all the material for investigation into near-death experiences, from which we obtain such glowing pictures of the after life, are gathered some time after the fact. On the basis of either one or both of the cases of suppression afforded by Rawlings, I am inclined to regard all statistical evidence for the lack of punishment of damnation after death, based as it is almost wholly on after-the-fact reports, as highly suspect. The very least one can conclude concerning the results of such methodologically flawed investigations is that no reliable conclusions, even tentative, can be drawn about the absence of a judgmental God, purgatory and hell.

\section{REFERENCES}

I. Moody. Raymond A., Jr.. M.D., Life After Life (Atlanta: Mockingbird Books, 1975). This work and the one that followed it, Reflections on Life After Life (Atlanta: Mockingbird Books, 1977), seem to have sparked a wave of interest in the topic and an increase in publication. Later psychological and sociological investigators tend to depreciate Moody's work somewhat because he does not use a statistically inspired methodology, Yet his conceptual framework is more sound than most, perhaps because of his initial background in philosophy and subsequent training in medical school. Anyone's work in this area may become somewhat dated because of the lack of data and flaws in methodology and narrow conceptual frameworks, but Moody's two works are probably still the most readable and stimulating introduction to the topic. Moody became interested in the topic partly through his contact, in 1965, with George Ritchie, a clinical professor of psychiatry in the School of Medicine at the University of Virginia at the time, and one who had had a lengthy out-of-body experience years before. Chapter 5 in Life After Life, "Explanations", is Moody's account of various attempts to explain away near death out-of-body experiences as something other than what they seem to be. Other accounts of alternative explanations may be found in Karlis Osis and Erlendur Haraldsson, Al the Hour of Death (N.Y.: Avon Books, 1977), and in Craig R. Lundahl, A Collection of Near-Death Research Readings (Chicago: Nelson-Hall Publications. 1982) essays 1(11-15), 5(76-87), 8(155-158), 12(214-227).

2. Gallup, George, Jr, and William Proctor, Adventures in Immortality (New York: McGraw-Hill, 1982). The statistics are interesting but the book is rather uninspired. The conceptual framework is not very sophisticated and the authors do not seem especially acquainted with the literature in the field.

3. Elisabeth Kubler-Ross is supposed to have done a good bit of work on near-death experiences and to have extensive files on the subject. (John Audette reports she has studied over one thousand cases. Cf. John R. Audette, "Historical Perspectives on Near-Death Episodes and Experiences", in Craig R. Lundahl, op. cil.. pp. 21-43, p. 39. n.I. She has not. as far as I know, published her material in a systematic way. She has been interviewed on 
the topic a number of times and has given lectures about it. Some of the interviews are: Linda Witt, "Life After Death: Yes. Beyond a Shadow of a Doubt", People 4:21 (1975)6669: Kenneth L. Woodward, "There is Life After Death". Mc Call's (August. 1976) pp-97139: Ann Nietzke, "The Miracle of Kubler-Ross", Human Behavior 6:9(1977)18-27. Unfortunately, as will be indicated later in this essay, Kubler-Ross has been a bit hasty in the philosophical-religious conclusions she has jumped to and has combined her experience with near-death experiences of patients with an interest and involvement in the occult. See E. Kubler-Ross (text). Mal Warchaw (photographs), To Live Until We Say Goodhye (Englewood Cliffs, N.J..: Prentice-Hall Inc., 1978). On p. 107, in a letter from one Louise, written to Mal Warshaw in May, 1978, we read: "After a visit from Elisabeth one time (last year), she said she would like to give me a gift and invited me to an overnight visit with her friends who joined her in her life-after-death research. I stayed only overnight but what those few hours meant to me! It was there that I had a rare and unique opportunity to get in touch with my own guides and soulmates. Gentry and Cecilia. They permitted me to touch them and then escorted me into a private little room (without the aid of my walker) for a private talk to have any questions answered about life before as well as hereafter, that they could, .... it was then I was told that Cecilia is the one who helps me with my painting." The comments and context indicate that Gentry and Cecilia, to whom Louise was introduced at Elisabeth's house are visitors from the spirit world. One is led to conclude that these spirit visitors are also the "friends who join her (Elisabeth) in her life-after-death research," Somewhat the same thing happened with Dr. Robert Crookall, an earlier researcher of out-of-body experiences who had done more work in the area than just about anyone now living. It is probably because of his strong theosophical inclinations that present investigators avoid Dr. Crookall's works. One might recall here that Edgar Cayce was led into the occult after years of coming to trust his "gift" as a healer.

4. Rawlings, Maurice, M.D., Beyond Death's Door (Nashville, Tenn.: Thomas Nelson Inc.. 1978). Dr Rawlings is a cardiologist whose interest in near death experiences dates from his resuscitation of a patient who kept screaming he was in hell. Rawlings's work is important because of his willingness to take the possibilities of heaven and hell seriously. and because of his reporting of near-death accounts of persons descending to a state sounding much like hell. Perhaps even more important is the way in which a couple of his cases suggest a serious methodological flaw in the work of most investigators. This will be considered at the end of this paper.

5. Sabom, Michael B., M.D., and Sarah S. Kreutziger have co-authored a number of essays on near-death experiences: "The Experience of Near-Death", Death Education I (1977)195-203; "Near-death Experiences letter". New England fournal of Medicine 297(1977)1071: "Insight into the Process of Death letter". Psvchology Today 10(1977)7: "Physicians Evaluate the Near-Death Experience", in Lundahl, op. cil. pp. 148-159. Sabom is a cardiologist and Kreutziger is an assistant professor of social work in psychiatry. They began interviewing survivors in 1976 with the intent, in part, of making physicians more aware of these occurences. Some of the publications of Sabom on his own are: "Near-Death Experiences: A Medical Perspective", paper presented at Founder's Day, Psychical Research Foundation (May, 1980): "Commentary on 'The Reality of Death Experiences' by Ernst Rodin". J. Nerv. Ment. Dis. I68(1980)266-267; Recollections of Death (New York: Harper and Row, 1982 [or 1981]).

6. Concerning Schoonmaker, see J. Audette, "Denver Cardiologist Discloses Findings After 18 years of Near-Death Research", Anabiosis I(1979) I-2, and the remarks of Craig Lundahl in "Directions in Near-Death Research", in Lundahl, op. cit., p.235, and Michael Grosso, "Toward an Explanation of Near-Death Phenomena", in Lundahl. op. cil.. p. 216. Interesting in the report of Shoonmaker's work is the noting of 55 cases "in which resuscitated NDE patients displayed flat electroencephalograms" (Cf. Grosso, op. cit, p.216).

7. Osis, Karlis, Deathed Observations by Physicians and Nurses (N.Y.: Parapsychology Foundation, 1961). Osis and E. Haraldsson, "Deathbed Observations by Physicians and Nurses: A Cross-Cultural Survey". Journal of the American Society for Psychical Research 71(1977)237-259; Osis and Haraldsson, At The Hour of Death (New York: Avon 
Books. 1977) [their most well known work] "Correspondence: Reply to Dr. Palmer",Journal of the American Society for Psychical Research 72(1978)395-400; “Correspondence: Reply to Dr. McHarg", Journal of the ASPR 73(1979)126-128. Osis's work was initially inspired by Sir William Barrett, a physicist of the Royal College of Science, Dublin, who presented some cases of death-bed visions in his work Death-Bed Visions (London: Methuen, 1926).

8. On Erlendur Haraldsson, see n.7. Haraldsson is an associate professor of psychology at the University of Iceland and a younger co-worker of K. Osis.

9. Ring, Kenneth. Life at Death: A Scientific Investigation of the Near-Death Experience (New York: Coward, McCann and Geoghegan. 1980): "Frequency and Stages of the Prototypic Near-Death Experience" in Lundahl, op. cit., pp. 110-147; Ring and Stephen Franklin, "Do Suicide Survivors Report Near-Death Experiences?" in Lundahl, pp. 18020I. Ring is a professor of psychology at the University of Connecticut who, as he indicates (Lundahl. p. 110) was led to undertake his research "as a direct result of reading Dr. R. Moody's first book. Life After Life."

10, Ray Kletti is a clinical psychologist in Manitowoc, Wisconsin. See the note on Noyes-

11. Noyes, Russell. Jr., M.D., "Dying and Mystical Consciousness", Journal of Thanatology I(1971)25-41; "The Experience of Dying". Psychiary 35(1972)174-184: "Panoramic Memory: A Response to the Threat of Death". Omega 8(1977)181-194; "NearDeath Experiences: Their Interpretation and Significance", in R. Kastenbaum, ed., Between Life and Death (New York: Springer Publishing Co., 1979); Noyes and Kletti, "Depersonalization in the Face of Life Threatening Danger: A Description". Psychiarry 39(1976) 19-27: Noyes and Kletti, "Depersonalization in the Face of Life Threatening Danger: An Interpretation", Omega 7(1976)103-114. Noyes and Kletti are among those who do not take the near-death experiences at face value, but characterize them as internal resources for coping with death. In Lundahl's work (op. cit.), they are criticized both by Sabom and Kreutziger (p. 156) and Grosso (pp. 218-219). Noyes is a professor of psychiatry at the University of Iowa.

12. George G. Ritchie's story is a fascinating one. After being pronounced dead with double lobar pneumonia as a young soldier stationed in Texas, he had an extended out-of-body experience with clear religious components to it. He subsequently went through medical school and then became a psychiatrist. He it was who had a strong influence on Moody. Moody dedicated his Life After Life to Richie and acknowledged a debt to him in Reflections on Life after Life. It is curious to note that there is not one reference to Richie in the bibliographies of Lundahl's work. Richie's story is told in his work Relurn From Tomorrow (Grand Rapids, MI: Chosen Books, 1978).

13. For Kreutziger, see n. 5.

14. Lundahl, Craig R., "Mormon Near-Death Experiences", Free Inquiry in Creative Sociology 7(1979)101-104. 107; compiler. A Collecrion of Near-Death Research Readingy (Chicago: Nelson-Hall Publishers, 1982). Lundahl is an associate professor of sociology at Western New Mexico University.

15. Widdison. Harold A., "Near-Death Experiences and the Unscientific Scientist", in Lundahl, op. cit.,pp. 3-17. Widdison's essay is a critique of the empiricist assumptions and narrow-mindedness of many scientists when faced with reports of near-death experiences. $\mathrm{He}$ is an assistant professor of sociology at Northern Arizona University.

16. Hart, Hornell. The Enigma of Survival (Springfield, IL: Charles C. Thomas Publishers, 1951): "Six Theories about Apparitions", Proceedings of the Society for Psychical Research 50(1956)153-239. Hart was at one time director of the International Project for Research on ESP Projection, and a professor at Duke University.

17. Grosso, Michael, "Near Death Experience and the Eleusinian Mysteries", paper presented at Founder's Day, Psychical Research Foundation, April. 1979; "Toward an Explanation of Near-Death Phenomena", in Lundahl, op. cit., pp. 205-230. Grosso is an assistant professor of philosophy at Jersey City State College.

18. H.H. Price was emertius professor of logic at Oxford University. There is an article of his concerning astral travel (out-of-body experience) in the Proceedings of the Society for Psychical Research 53(1961). 
19. Ducasse, C.J., A Critical Examination of the Belief in a Life After Death (Springfield, IL: CC. Thomas Pub, 1961). On page 160 of this work, Ducasse draws attention to the cord connecting the two "bodies" of one who is having an out-of-body experience.

20. James, William, Varietics of Religious Experience (New York: American Library. (1958).

21. Crookall, Robert, The Studv and Practice of Astral Projection (Stockbridge. Mass.: Aquarian Press, 1960): More Astral Projection (Stockbridge, Mass.: Aquarian Press. 1964): Events on the Threshold of the After-Life (Moradabad. India: Darshana. International, 1968). Crookalt had a background in botany and geology before becoming involved in near-death experiences. One can learn much from Crookall without necessarily adopting his theosophical viewpoint.

22. Monroe, Robert A., Journeys Out of the Body (Garden City, N.Y.: Doubleday and Co., Inc., 1973). It is hard to know what to make of Monroe. His very detailed accounts of travels out of his body seem open to, but are not defenses of, the after death states of heaven and hell. His accounts seem also to suggest life either on other planets. or in another dimension (whatever that would mean). Different older practitioners of travels out of the body have been uneasy about teaching others how to do it since they instinctively feel danger associated with the experiences. Monroe seems to have no such hesitation. Monroe's experiences, like those of anyone else, are valuable insofar as they can be correlated with and checked by those of others.

23. Cf. n. 15 .

24. Cf. n. 3 .

25. Cf. n. 2.

26. Ryle. Gilbert. The Concept of Mind (New York: Barnes and Noble, 1949). This work is often regarded as a modern classic. The horse he stalks is Descartes dual substance theory which he inclines to read back into ancient and medieval thought. Insofar as Ryle defends a unity of human nature, he tends to behaviorism.

27. Aquinas, St. Thomas, On the Truth of the Catholic Faith, Book 2, Creation, trans. by James F. Anderson. Ch. 46-90, esp. Ch. 68-72.

28. On Lucy of Fatima, see Francis Johnston, Fatima: The Great Sign (Rockford, 1L: Tan Books and Publishers, Inc., 1980), p. 36. See also the vision of Jacinta, pp. 36-7. Thesc visions, as well as those of Anna-Maria Taigi, are not out-of-body experiences, but visions coming from God to someone in their normal bodily condition.

29. On Anna-Maria Taigi, see Albert Bessieres, Wife, Mother and Mystic, trans, by Rev. Stephen Rigby, ed. by Douglas Newton (Rockford, 1L; Tan Bookș and Publishers. Inc.. 1970). p. 184 ,

30. Cf. R. A. Moody,Jr., "The Experience of Dying" in Lundahl, op, cit..pp. 89-109, pp. 97-98: "Over and over. I have been told that once they became accustomed to their new situation, people undergoing this experience began to think more lucidly and rapidly than in physical existence.

Perception in the new body is both like and unlike perception in the physical body, In some ways, the spiritual form is more limited. As we saw, kinesthesia, as such, is absent. In a couple of instances, persons have reported that they had no sensation of temperature, while in most cases feelings of comfortable "warmth" are reported. No one among all of my cases has reported any odors or tastes while out of their physical bodies."

On the other hand, senses which correspond to the physical senses of vision and of hearing are very definitely intact in the spiritual body, and seem actually heightened and more perfect than they are in physical life. One man says that while he was 'dead' his vision seemed incredibly more powerful and. in his word. "I just can't understand how I could see so far:'A woman who recalled this experience notes. 'It seemed as if this spiritual sense had no limitations, as if I could look anywhere and everywhere.'

"'Hearing' in the spiritual state can apparently be called so only by analogy. and most say that they do not really hear physical voices or sounds. Rather, they seem to pick up the thoughts of persons around them.... 
"In this disembodied state, then, a person is cut off from others. He can see other people and understand their thoughts completely. but they are able neither to see nor to hear him. Communication with other human beings is effectively cut off, even through the sense of touch, since his spiritual body lacks solidity."

31. See. for example, Ryle, op. cit., p. 23.

32. The late professor, Anton Pegis, was fond of this way of defining being human, in accordance with the mind of St. Thomas.

33. Thomas, St,. Summa theologiae 1,89.1.c and $3^{\mathrm{m}}$. Cf. A.C. Pegis, "The Separated Soul and its Nature in St. Thomas" in St. Thomas Aquinas 1274-1974: Commemorative Studies 2v. (Toronto: Pontifical Institute of Mediaeval Studies, 1974), vol. I. pp. 13I-158.

34. Since the loss of a limb hardly affects the functioning of the senses on which we depend to gain knowledge, a more appropriate analogy might be irreparable brain damage which left only the sense of sight intact. The analogy still limps, as do all analogies. It is the seeming removal of the body as the basis of the functioning of all our senses, especially that of touch. which makes death such a great natural evil.

35. This "body of sorts" is variously referred to as a spiritual body. an astral body. an ethereal body, an electromagnetic body, the spirit (as opposed to the soul), and is sometimes confused with the soul itself as the principle of life.

36. Carty. Rev. Charles Mortimer, Padre Pio the Stigmatist. (Rockford. IL: 1973), p. 69. There are many cases of supernaturally caused out-of-body experiences. There are many cases of apparently naturally occurring out-of-body experiences. Then there are many cases in which one cannot say whether their origin is natural or supernatural. But the philosophical problem of the unity of the person as a conscious being is the same (assuming the soul still vivifies the body) whether the cause is natural or supernatural.

37. See Into the Unknown (Pleasantville, N. Y.: Reader's Digest, 1981), pp. 272, 274, 276. Dr. R, Crookall often wrote of the cord. It is true, however, that the cord is usually not noticed (or commented on) by those having an out-of-body experience, and most modern researchers seem quite unaware of this possible aspect of the experience.

38. Ihid.. p. 283 . See n. 6.

39. See Herbert B. Greenhouse, The Astral Journey (New York: Avon Books, 1974), p. 326.

40. Shouppe. Rev. F. X., S.J., Purgatory: Illustrated by the Lives and Legends of the Saimı, 1893 (Rockford, IL: Tan Books, 1973).

41. Quoted in Albert Bessieres. loc. cit.

42. See Francis Johnston. op. cil., p. 36.

43, Ihid., pp. 36-7.

44. Quoted in Svetozar Kraljevic, O.F.M.. The Apparitions of Our Lady At Mediugorie (Chicago: Franciscan Herald Press, 1984), p. 122.

45. See Rawlings, op. cit., p, 100.

46. Martin. Ralph. A Crisis of Truth: The Altack on Faith. Moralin. and Mission in the Catholic Church (Ann Arbor, MI: Servant Books, 1982) p. 157. See also n. 3.

47. See Raymond A. Moody. Jr.. "The Experience of Dying", in Lundahl, op, cit.. pp. 89-109. p. 108. For a somewhat opposing view in the same volume, see Charles A. Garfield. “The Dying Patient's Concern With Life After Death", pp. 160-164. especially p. 162.

48. The most popular work on multiple personalities has been Sybil.

49. Cf. K. Ring and S. Franklin, "Do Suicide Survivors Report Near-Death Experiences?" in Lundahl. op. cit.. pp. 180-200. especially pp. 196-200. The hypothesis of Ring and Franklin. that those attempting suicide are really after an experience of transcendence and cease attempting suicide after such an experience, is both ad hoc and implausible. If one were willing to risk one's life for an experience of transcendence and got a brief pleasant taste of it and then had to return to the same old routine, why would not one head right back for a longer taste? It makes no sense to me unless one has had not only a pleasant experience of sorts but also a clear warning of intimation that to end one's life is wrong and seriously so.

50. Rawlings, op, cil., p. 5.

51. Rawlings. op, cir., p. 95. 